\title{
The Rising Tide: Some Implications for College and University Libraries
}

$\mathrm{P}$ ERHAPS THE TITLE given this paper is a bit ambiguous as well as ambitious, and it may need some clarification. University librarians are all too familiar with the problem which their libraries have faced and are facing as a result of the tremendous growth of book collections in recent decades. That matter of library growth has been dealt with thoroughly in the professional literature, and requires no amplification. The object here will be to cover briefly another growth problem which will confront college and university libraries over the next two decades.

This is the proliferation of students which will come as a result of the rising tide of enrollments-already crowding our elementary and secondary schoolswhich will spill over into the colleges and universities in the next fifteen years. In the past, libraries have struggled to find places to put their books. In the future they will also have to find space to put their students, and to provide the services to bring those books and students together.

Perhaps a review of the already wellpublicized statistics will illustrate the magnitude of the enrollment increases in store for our colleges and universities. Last school year there were over 3,250,000 students enrolled in institutions of higher education throughout the nation. "This record comes at a time when the college-age population, which in 1955

Mr. Brock is Assistant, Social Sciences Division, Florida State University Library. sank to its lowest point in twenty-five years, is still made up mostly of depression babies. The crisis that the U.S. campus is now bracing for is the coming invasion of war babies."1 By 1970, barring some national catastrophe, there will be over 6,000,000 students enrolled. ${ }^{2}$ This estimate by the Times is among the more conservative ones. One qualified writer foresees $7,500,000$ by $1975,{ }^{3}$ while other 1970 estimates run as high as 9,000,000, three times the number we now have. ${ }^{4}$

These statistics, spread in the abstract over a nationwide basis, may sound like remote and harmless figures, something dredged up by educational prophets of doom to extort more money from parsimonious legislatures. Viewed in a specific situation, however, they take on more meaning. Last year the enrollment at the University of Michigan, for instance, was slightly over 20,000 ; by 1970 , according to official figures, there will be over 40,000 students on the campus.

Truly, "revolutionary changes are occuring in American education of which even yet we are only dimly aware."5

It used to be an aphorism in educational circles that the best way to facilitate the learning process was to put a student on one end of a $\log$ and Mark Hopkins on the other. One seldom hears that today, and perhaps it is just as well. For one thing, if the pun be permitted, the likes of Mark Hopkins do not grow

1 Time (Feb. 4, 1957), p. 41.

2 New York Times, October 21, 1956, IV, p. 9

${ }^{3}$ Peter F. Drucker, "Will the Colleges Blow Their Tops?," Harper's Magazine, (July, 1956), p. 63

New York Times, November 25, 1956, IV, p. 9

5 President's Committee on Education Beyond the High School, Second Report to the President (Washington, D. C., 1957) p. 1. 
on trees. And even if they did, given the statistics cited above, there might not be enough logs to go around.

But just what do these rather sobering statistics mean? They mean for one thing that our colleges and universities will have to choose between two alternatives: (1) maintain their present size, while raising entrance requirements to keep out all but the cream of high school students, or (2) expand.

To take the first of these courses would mean that tomorrow's entering freshman would need a full head as well as a full purse. Judging from the tenor of thinking in the academic world today, however, there seems little likelihood that this "man the barricades" alternative will be taken. The President's Committee on Education Beyond the High School, in its second report, states that "our ideals and the increasing complexity of our civilization require that each individual, regardless of race, creed, color, or national origin, have the opportunity to pursue education or training beyond the high school to the full extent he or she is willing and able."6

The President's Committee, perhaps sobered by its own troubles with an economy-minded Congress, later states that "if an unwelcome choice were required between preserving quality and expanding enrollments, then quality should be preferred. . .."7 Even if we allow for some restrictions on enrollment, however, all available evidence still points to a period of unprecedented expansion for the nation's universities and colleges.

Assuming then, as we must, that enrollment increases--with the resulting expansion-are inevitable and permanent for so long as we can forsee, what are some of the effects we may expect such increases to have upon academic libraries?

\footnotetext{
Ibid., p. ix.
}

7 Ibid., p. 4.
Father Paul C. Reinert, president of St. Louis University and a member of the President's Committee, dealt with some of the general effects which may be expected in his speech to the ACRL last June in Kansas City. ${ }^{8}$ The following is an attempt to extend his discussion into more specific areas.

Here it must be pointed out, even emphasized, that this paper becomes frankly speculative. No one can predict with any certainty what changes will come to college and university librarianship in the next fifteen years, and to attempt to do so would be foolish. But we can safely assume that there will be changes, and to refuse to try to anticipate them would be equally foolish.

For one thing, buildings which in many cases are already inadequate will become even more crowded and antiquated. In 1951, after a survey of the building plans of over 100 college and university libraries, Dr. Robert H. Muller said: "Present seating capacities are insufficient in many of the libraries, especially in those of larger institutions. Out of eighty-seven libraries reporting seating capacity, only sixteen provided seats for 20 per cent or more of the 1948 student body in their old library buildings. Library buildings of the future (those to be built by the 100 libraries before 1960) will provide for not less than 10 per cent of the 1948 enrollment." 9 The minimum accepted percentage of student seating, at least until today, was usually set at about 25 per cent. For purposes of hypothesis let us assume that university $X$ had an enrollment in 1948 of 6,000 students and constructed in 1954 a building which would seat 30 per cent of its 1948 student body. We can assume that by 1970 university $X$ will have at least 12,000 students. At that time the build-

8 Paul C. Reinert, S.J.. "College and Research Libraries in a Decade of Decision," $C R L$, XVIII, (1957), 359-365

g Robert H. Muller, "Future Library Building Trends Among Colleges and Universities," $C R L$, XII, (1951), 35 
ing, then only sixteen years old, will seat only 15 per cent of the student body.

It would appear, then, that recent college and university building programs were belated efforts to catch up with past expansion rather than in anticipation of the future, at least in regard to student seating. Since the population experts themselves failed to predict the present baby boom, this failure to anticipate cannot be laid at the door of librarians. This helps very little, however, since it is the librarians who now must find money for buildings which will accommodate the future wave of students.

One recommendation of the President's Committee, if acted upon, might be of help in this area. The Committee recommended that Federal grants-in-aid be made available to assist institutions of higher education in constructing needed non-income-producing facilities such as laboratories, classrooms, and libraries. ${ }^{10}$

The effect of increased enrollments on the college and university library book collection is impossible to predict with any accuracy. Lyle says that "there is a very definite correlation between the size of the college and the number of volumes added annually to its library." 11 If such a correlation holds true in the future it would indicate that book budgets will also balloon as enrollments rise. The college library may be affected more than the university library in this area, but both will feel some effects. At the very least, the increases will mean that a greater portion of the book budget will be channelled into the purchase of duplicates.

More students on the campus will of course mean more students in the library. This in turn will mean a greater burden on the library's public service departments, on the routines by which

10 President's Committee on Education Beyond the High School, op. cit., p. 89.

${ }_{11}$ Guy R. Lyle, The Administration of the College Library. (New York: H. W. Wilson Co., 1944), p. 330 . books are circulated and interpreted. In past years, due to the burgeoning of book collections, the acquisitions and cataloging people, struggling to keep up with an increasing flood of books, have often felt like the tortoise when told he had been matched against the hare. In the next fifteen years their circulation and reference colleagues may join them in an equally one-sided race.

The enrollment increases could also mean, especially in the large university libraries which must try to maintain some balance between research and instructional material, that services may receive increasing attention at the expense of resources. The current trend toward undergraduate libraries, as exemplified by Harvard and most recently by Michigan, can be viewed in one way as an attempt to resolve this conflict.

Enrollment pressure might also force the larger universities, with their farflung graduate and research programs, farther down the road toward specialization. $^{12}$

As far as the library staff is concerned, the increases may mean that more and more student and subprofessional help will be employed, and that the ratio of professional to clerical staff will decline. This would place an increasing burden of supervision on the professional staff, but in the process it might solve the Gordian knot of the division of professional and clerical work.

But perhaps the greatest strain will fall upon administrators in dealing with aspects of financial support for the library. In the years ahead competition for the educational dollar, both within and without the university, will be terrific. It must be remembered that, before this wave of students reaches the colleges, they will have passed through the elementary and secondary schools.

\footnotetext{
12 Clifton Brock, "Specialization and the Rising
Tide-Two Waves of the Future?" $C R L$, XVII, Tide-Two Waves
(1956), 486-490.
} 
During these years the taxpayers will have to pour more and more money into education. By the time the students reach the colleges and universities it may become a case of getting blood from the proverbial turnip.

Also, with the university the competition for support among departments of instruction and among various functional units of the university will be greater. In the past, during the years when the library was grappling with the problem of increasing book collections, academic enrollments remained relatively stable. This meant that the library could absorb a large proportion of the educational budget without meeting implacable opposition from departments of instruction and other areas of the school. In the future this will not hold true.

Earlier it was stated that there were only two alternatives which colleges and universities could take in the face of enrollment increases-either raise entrance requirements or expand. But with increasing frequency of late there have appeared in the educational literature various proposals which are put forward as solutions which might obviate the necessity of making such a harsh choice. Most of these plans center around the use of television in teaching, making it possible for a few faculty members to reach greater numbers of students, thus relieving schools of the necessity of practically doubling their faculty and classroom facilities.

That there will be extended use of educational television in the future seems inevitable, despite the anguished and perhaps justified cries of those who fear it. Several state departments of education have already carried it beyond the experimental stage on the secondary education level, and various universities are now approaching it cautiously. The President's Committee recommends that there be "vigorous and objective explo- ration and application of methods of increasing the effectiveness and productiveness of the teacher, including electronic devices such as television. . . ."13

"Television" is a scare-word for many librarians, and it is not my intention here to describe all the devils which its mention may evoke. There could be great danger for academic libraries in the use of television in teaching, however, unless librarians are consulted, or see to it that they are consulted, during the planning stages of such ventures. This can be very pointedly illustrated.

One college official, who shall remain anonymous, recently advanced a plan involving these three propositions: (1) use of the so-called European method of teaching, which means fewer lectures and textbooks but much more work on the part of the student in the library, (2) use of the old correspondence school idea, and (3) use of television. He would limit the number of students on a campus to 10 per cent of the total enrollment or, say, to 1,000 out of a total of 10,000 . In the surrounding towns and cities, over a radius of perhaps two or three hundred miles, he would have the other 90 per cent, or 9,000 students, who would go to college by television, tuning in each day at appointed hours for their lectures. In this way a large number of students would receive the benefit of expert teaching, and the school would have to expand its physical plant only slightly.

It is a fascinating proposal, but there is just one difficulty. The plan calls for the European method of teaching, which forces the student into the library much more than our present system. But where is the library in this plan? These 9,000 students out in the educational sticks, so to speak, cannot hope to find the materials they need in their local libraries, and the university must provide them.

13 President's Committee on Education Beyond the High School, op. cit., p. 36 . 
Without belaboring the point any further, it seems obvious that such a plan, if carried out, would make the library an academic Sears Roebuck, sending and receiving books by the thousands, with the shipping and receiving section of the library taking perhaps 80 per cent of the budget.

This is of course an extreme case, and there is little likelihood that it would ever be carried out. The fact that it was seriously proposed, however, should inspire librarians to watch carefully any budding plan for educational television within their institutions.

Another movement, also designed to alter teaching methods with a view toward relieving the necessity for expansion, is gathering momentum. One of its most lucid advocates, Henry Steele Commager of Columbia University, describes the plan in the January 29, 1956, issue of the New York Times Magazine. By way of background, Commager has this to say: "We are the prisoners of our own traditions and habits, and particularly, the prisoners of one tradition that has come down through the centuries-the tradition of the lecture. We still tend to think of teaching as it was centuries ago, before the rise of the university library and the development of library science -a science more highly developed in the United States than elsewhere in the world. We still refuse to learn what $\mathrm{Ox}$ ford and Cambridge, for example, have taken to heart, that lectures often interfere with learning, that professors cannot be expected to do all the teaching, and that a major part of education is and should be performed by the students themselves."

Professor Commager proposes that we reduce drastically our use of the lecture. "Now that students can read for themselves, the English universities have turned more and more from lectures to tutoring or to self-education ... but in the United States, which has the best li- brary facilities in the world ... professors go on 'giving' courses as blithely as if no printed books were available. One very simple way, then, to meet the shortage of teaching talent, is to cut down on the lectures and therewith reduce the number of professors that lectures call for. From the point of view of the student, the time spent going to lectures and preparing for course examinations can more profitably be spent in the library."

This tendency away from textbook and lecture teaching has now assumed the proportions of a definite trend. Time magazine recently surveyed the progress made along these lines in colleges and universities across the country. Speaking of a program at Iowa's Grinnell College, which allowed the student to earn a fourth credit for extra independent study done in three-hour classes, Time said: "Though neither professors nor students are entirely satisfied with the program, it at least has forced the library to double the number of books it buys each year."'14

From the above it seems obvious that, regardless of the road higher education takes-that of expansion or that of revision of teaching methods-the library is in for a period of unprecedented change. If a minor change in teaching methods can force a library to double its book budget, then academic libraries during the next few years are going to be very interesting places.

The function of the library, and especially of the academic library, is to bring the book and the student together. In the past librarians have often complained that their efforts along that line have been ignored or passed unappreciated. In the future it looks as if they will have an opportunity and a challenge to make the library as important a part of college and university instruction as they know it should be.

14 Time, (April 15, 1957), p. 87. 